\title{
EVALUATION OF ANTI-INFLAMMATORY AND ANTI-ARTHRITIC ACTIVITY OF ETHANOLIC EXTRACT OF LEAVES OF NYCTANTHES ARBOR-TRISTIS ON EXPERIMENTAL ANIMAL MODELS
}

\author{
Pallavi Bordoloi ${ }^{1}$, Tarali Devi², Mangala Lahkar ${ }^{3}$
}

${ }^{1}$ Assistant Professor, Department of Pharmacology, Assam Medical College, Dibrugarh.

${ }^{2}$ Assistant Professor, Department of Pharmacology, Assam Medical College, Dibrugarh.

3 Professor, Department of Pharmacology, Gauhati Medical College, Guwahati.

\begin{abstract}
BACKGROUND
Inflammation is characterised by pain, redness, swelling and tenderness. Usually, conventional anti-inflammatory drugs are used to treat inflammation. But these drugs have side effects like acceleration of damage and erosion of joint spaces and advance osteoporosis. Traditionally, Nyctanthes arbor-tristis has been used to treat various diseases. So, the present study is undertaken to evaluate the anti-inflammatory and anti-arthritic activities of Nyctanthes arbor-tristis.

Aim- The present study was designed to evaluate the anti-inflammatory and anti-arthritic activity of the ethanolic extracts of leaves of Nyctanthes arbor-tristis (EENA). The extract was prepared by percolation method and acute oral toxicity test was performed as per OECD guidelines.

Objectives-

1. To evaluate the anti-inflammatory activity of Nyctanthes arbor-tristis against acute inflammation by Carrageenan induced rat paw oedema method.

2. To evaluate the anti-arthritic activity of Nyctanthes arbor-tristis against chronic inflammation by adjuvant arthritis method.
\end{abstract}

ABSTRACT

\section{MATERIALS AND METHODS}

Acute inflammation was studied by Carrageenan induced rat paw oedema method and paw volumes were measured at various intervals. Activity against chronic inflammation was studied by Freud's complete adjuvant induced arthritis method. Paw volumes were measured on $1^{\text {st }}$ day, $5^{\text {th }}$ day (injected paws) and on $21^{\text {st }}$ day. Aspirin was taken as the standard drug for all the experiments and a control group was maintained in all the models.

\section{RESULTS}

EENA showed highly significant $(\mathrm{p}<0.05)$ anti-inflammatory activity against carrageenan induced acute inflammation at the end of $4^{\text {th }} \mathrm{hr}$. It also showed significant reduction $(\mathrm{p}<0.05)$ of exudates formation in all the doses. In Freud's complete adjuvant induced arthritis model, EENA significantly reduced primary and secondary lesions when compared to the control. Both $200 \mathrm{mg} / \mathrm{kg}$ and $400 \mathrm{mg} / \mathrm{kg}$ of EENA significantly $(\mathrm{p}<0.05)$ down-regulated the index of arthritis and they reduced $(\mathrm{p}<0.05)$ the decrease in weight in the adjuvant arthritis rats as compared to the control group on the $21^{\text {st }}$ day of adjuvant injection. In chronic inflammation, significant inhibitions of paw oedema and weight reduction were found.

\section{CONCLUSION}

Based on the findings, we can conclude that the ethanolic extract of leaves of Nyctanthes arbor-tristis contains anti-inflammatory and anti-arthritic activity.

\section{KEYWORDS}

Anti-Inflammatory, Anti-Arthritic, Nyctanthes Arbor-Tristis, Aspirin, Flavonoids.

HOW TO CITE THIS ARTICLE: Bordoloi P, Devi T, Lahkar M. Evaluation of anti-inflammatory and anti-arthritic activity of ethanolic extract of leaves of Nyctanthes arbor-tristis on experimental animal models. J. Evolution Med. Dent. Sci. 2018;7(10):1247-1251, DOI: $10.14260 /$ jemds/2018/284

\section{BACKGROUND}

Inflammation is a complex reaction to injurious agents such as microbes and damaged usually necrotic cell that consists of vascular responses, migration and activation of leukocytes and systemic reactions. It is part of the host's defence, but when the response becomes too great it may be far worse

'Financial or Other Competing Interest': None.

Submission 22-01-2018, Peer Review 15-02-2018,

Acceptance 21-02-2018, Published 05-03-2018.

Corresponding Author:

Dr. Pallavi Bordoloi,

Assistant Professor,

Department of Pharmacology,

Assam Medical College,

Dibrugarh-786002.

E-mail: drpallavi.bordoloi3@gmail.com

DOI: $10.14260 /$ jemds $/ 2018 / 284$

\section{(c) $(1)(5)$}

than the disease state which is counteracted and in extreme cases it may be fatal. The characteristics of inflammation are numerous, reddening if it is visible, swelling (oedema), soreness and the corresponding histological changes. ${ }^{[1]}$

Rheumatoid arthritis is a chronic inflammatory autoimmune disorder involving multiple systems.[2] It mainly affects joints in a polyarticular manner. It is characterised by progressive joint destruction, deformity, disability and premature death. Currently, the main stream of treatment of RA is the non-steroidal anti-inflammatory drugs along with steroids. ${ }^{[3,4]}$ Long term treatment with NSAIDs and steroids is associated with lots of complications.[5]

Nyctanthes arbor-tristis (sewali, sephalika) is a large deciduous shrub or small tree with quadrangular branches, rough all over with an uneven epidermis and stiff white hairs. Leaves are ovate and acuminate with a few large distant teeth. It bears beautiful white flowers in profusion. It belongs 
to the family of Oleaceae and is widely distributed in tropical East Asia including India and Bangladesh. It is mainly used as an expectorant, bitter and tonic. It has a mild purgative action. It is used in bilious and obstinate remittent fever, sciatica and rheumatism. It is useful in constipation of children.[6,7]

\section{Objectives}

1. To evaluate the anti-inflammatory activity of Nyctanthes arbor-tristis against acute inflammation by Carrageenan induced rat paw oedema method.

2. To evaluate the anti-arthritic activity of Nyctanthes arbor-tristis against chronic inflammation by adjuvant arthritis method.

\section{MATERIALS AND METHODS}

\section{Plant Materials}

The leaves of Nyctanthes arbor-tristis were collected in the month of May from different parts of Dibrugarh district and were authenticated by Dr. LR Saikia, Professor, Department of Life Science, Dibrugarh University (Voucher specimen. No. DULSc447). The collected plant materials were cleaned, air dried at room temperature. The dried leaves were hand crushed and stored in airtight container.

The dried leaves of Nyctanthes arbor-tristis were finely ground and extracted overnight with ethanol (50:50) in cold. The materials were repeatedly extracted with hot ethanol in Soxhlet apparatus and extraction was done by continuous hot percolation using ethanol $(95 \% \mathrm{v} / \mathrm{v})$. The extract was concentrated using a rotary evaporator.[8] It was further concentrated and dried in desiccators. The extract collected as stored in air tight glass container in refrigerator at $2-8^{\circ} \mathrm{C}$ for further use in the experiment.

\section{Animals used in the Study}

Healthy albino rats of the species Rattus norvegicus of either sex weighing $150-200$ gm and healthy albino mice of the species Mus musculus of either sex weighing $20-30 \mathrm{gm}$ of either sex were selected for the experiments. Animals were obtained from central animal house, Guwahati Medical College, Guwahati. Animal studies were performed in accordance with CPCSEA guidelines and the study was approved by Institutional Animal Ethics Committee (IAEC Regd. No. 351/CPCSEA-3/1/2001). They were allowed to acclimatise to the laboratory environment for one week. They were housed in light-controlled room (12:12 hrs.) and at constant temperature $\left(22 \pm 2^{\circ} \mathrm{C}\right)$ conditions and fed with balanced laboratory diet and water ad libitum.

\section{Acute Toxicity Study}

Acute toxicity test was done for the ethanolic extract of Nyctanthes arbor-tristis following OECD[9] 425 guidelines. As the LD50 of EENA is found to be more than $2000 \mathrm{mg} / \mathrm{kg}, 100$, 200 and $400 \mathrm{mg} / \mathrm{kg}$ were selected for the study.[10]

\section{Experimental Design}

For each experiment, animals are divided into five groups with 6 animals in each group. Experimental design-

Group A (Control): Normal saline $10 \mathrm{ml} / \mathrm{kg}$ p.o.

Group B (Test): EENA $100 \mathrm{mg} / \mathrm{kg}$ p.o.

Group C (Test): EENA $200 \mathrm{mg} / \mathrm{kg}$ p.o.

Group D (Test): EENA 400 mg/kg p.o.

\section{Group E (Standard)}

Aspirin 100 mg/kg p.o.

\section{Anti-Inflammatory Study against Acute Inflammation}

Groups of rats were pre-treated with normal saline, test drug and standard drug per orally one hour before carrageenan injection. Freshly prepared carrageenan $1 \%$ in $0.9 \% \mathrm{NaCl}$ solution was injected in a volume of $0.1 \mathrm{~mL}$ into sub-plantar region of the right hind paw of the rats.[11] The foot volume was measured by plethysmometer just before $1^{\text {st }} \mathrm{hr}, 2^{\text {nd }} \mathrm{hr}$, $3^{\text {rd }} \mathrm{hr}$ and $4^{\text {th }} \mathrm{hr}$ after carrageenan injection. The volume of oedema was recorded as the difference between the paw volume at $0 \mathrm{hr}$ and at the end of each hour.[12] The percentage of anti-inflammatory activity was calculated.[13]

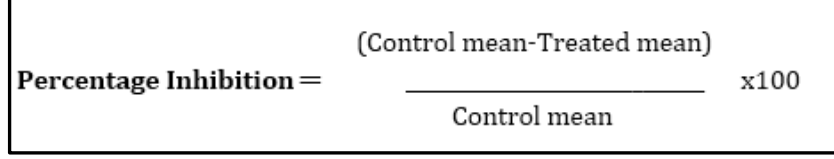

Anti-Inflammatory Study against Chronic Inflammation The anti-inflammatory activity of ethanolic extract of EENA against chronic inflammation was tested by Freund's adjuvant-induced arthritis method in rats.[14]

On day 1 , the arthritic syndrome is induced by the intradermal injection of $0.05 \mathrm{~mL}$ of a fine emulsion of dead tubercle bacilli $(5 \mathrm{mg} / \mathrm{mL})$ into the plantar surface of right hind paw of the rats. Treatment with the test compounds and the standards to the respective groups was started on the same day and continued for 12 days. The paw volumes of both sides and the body weights were recorded on day 0 . The paw volumes were measured plethysmographically.

On day 5 the volume of the injected paw was measured again, indicating the primary lesion and the influence of the therapeutic agent on this phase. The severity of the induced adjuvant disease was followed by measurement of the noninjected paw (secondary lesions) with a plethysmometer. Purposely, from day 13 to 21 , the animals were not dosed with the test compound or the standard. The following parameters are noted in the control and the treated groups throughout the study period-

a. Paw oedema.

b. The severity of the secondary lesions.

c. Body weight changes.

On day 21, the non-injected paw volume and the body weight were determined again ${ }^{[15]}$ and the polyarthritis severity were graded on a scale of $0-4$.

- $0=$ no swelling;

- $1=$ isolated phalanx joint involvement

- 2 = involvement of phalanx joint and digits;

- $3=$ involvement of the entire region down to the ankle;

- $4=$ involvement of entire paw including ankle.

The Maximum Joint Score was 12 including 3 Secondary Arthritis Paws for each Rat

1. For primary lesions: The percentage inhibition of paw volume of the injected right paw over control was measured at day 5 .

2. For secondary lesions: The percentage inhibition of paw volume of non-injected left paw over control was measured at day 21. 
3. An Arthritis index was calculated as the sum of the scores as indicated above for each animal.

\section{Statistical Analysis}

Statistical analysis will be done using one-way ANOVA followed by Dunnett's multiple comparison tests.[16] $\mathrm{P}$ value $<0.05$ will be considered significant. The results were calculated with the use of GraphPad Prism software version 5.0 .

\section{RESULTS}

Carrageenan induced rat paw oedema test

Results were given in Table I. The EENA in doses 200 and 400 $\mathrm{mg} / \mathrm{kg}$ showed significant acute anti-inflammatory activity as compared to control $(\mathrm{p}<0.01)$ as evidenced by significant decrease in paw oedema at the end of $4^{\text {th }} \mathrm{hr}$ in carrageenan induced rat paw oedema test.

\begin{tabular}{|c|c|c|c|c|c|}
\hline \multirow{2}{*}{ Drugs } & \multirow{2}{*}{$\begin{array}{l}\text { Dose/ } \\
\text { Route }\end{array}$} & \multicolumn{4}{|c|}{ Mean Increase in Paw Oedema (Mean \pm SEM) in $\mathrm{mL}$} \\
\hline & & 1st $^{\text {st }}$ & 2nd hr $^{\text {n }}$ & $3^{\text {rd hr }}$ & $4^{\text {th }} \mathbf{h r}$ \\
\hline A (Control) & $2 \mathrm{~mL}$ po & $\begin{array}{c}0.40 \pm 0.01 \\
(-)\end{array}$ & $\begin{array}{c}0.49 \pm 0.008 \\
(-)\end{array}$ & $\begin{array}{c}0.51 \pm 0.008 \\
(-)\end{array}$ & $\begin{array}{c}0.54 \pm 0.007 \\
(-)\end{array}$ \\
\hline B (EENA) & $\begin{array}{c}100 \mathrm{mg} / \mathrm{kg} \\
\text { po }\end{array}$ & $\begin{array}{c}0.32 \pm 0.01 \\
(14.2 \%)\end{array}$ & $\begin{array}{c}0.35 \pm 0.007 \\
(22.4 \%)\end{array}$ & $\begin{array}{c}0.36 \pm 0.007 \\
(23.1 \%)\end{array}$ & $\begin{array}{c}0.34 \pm 0.01 \\
(22.6 \%)\end{array}$ \\
\hline C (EENA) & $\begin{array}{c}200 \mathrm{mg} / \mathrm{kg} \\
\text { po }\end{array}$ & $\begin{array}{c}0.26 \pm 0.007 \\
(27.5 \%)\end{array}$ & $\begin{array}{c}0.29 \pm 0.009 \\
(31.4 \%)\end{array}$ & $\begin{array}{c}0.29 \pm 0.01 \\
(41.6 \%)\end{array}$ & $\begin{array}{c}0.28 \pm 0.01 \\
(49.8 \%)\end{array}$ \\
\hline D (EENA) & $\begin{array}{c}400 \mathrm{mg} / \mathrm{kg} \\
\text { po }\end{array}$ & $\begin{array}{c}0.23 \pm 0.004 \\
(36.1 \%)\end{array}$ & $\begin{array}{c}0.26 \pm 0.01 \\
(39.3 \%)\end{array}$ & $\begin{array}{c}0.22 \pm 0.008 \\
(48.1 \%)\end{array}$ & $\begin{array}{c}0.20 \pm 0.008 \\
(57.2 \%)\end{array}$ \\
\hline E (EENA) & $\begin{array}{c}100 \mathrm{mg} / \mathrm{kg} \\
\text { po }\end{array}$ & $\begin{array}{c}0.20 \pm 0.01 \\
(43.1 \%)\end{array}$ & $\begin{array}{c}0.22 \pm 0.008 \\
(44.9 \%)\end{array}$ & $\begin{array}{c}0.18 \pm 0.01 \\
(53.6 \%)\end{array}$ & $\begin{array}{c}0.16 \pm 0.008 \\
(64.1 \%)\end{array}$ \\
\hline \multirow{3}{*}{ One-Way ANOVA } & $\mathrm{F}$ & 69.09 & 115.9 & 192.2 & 270.8 \\
\hline & $\mathrm{df}$ & 4,25 & 4,25 & 4,25 & 4,25 \\
\hline & $\mathrm{P}$ & $<0.05$ & $<0.05$ & $<0.05$ & $<0.05$ \\
\hline
\end{tabular}

Table I. Anti-Inflammatory Activity of Ethanolic Extract of Nyctanthes Arbor-Tristis on Carrageenan-Induced Rat Paw Oedema at the End of $1^{\text {st }}, 2^{\text {nd }}, 3^{\text {rd }}$ and $4^{\text {th }}$ hour

$\mathrm{N}=6$ in each group; $\mathrm{p}<0.05$ vs. control.

\section{Adjuvant-Induced Arthritis in Rats}

Results were given in Table II. Significant and arthritic action was also observed with EENA in doses 200 and $400 \mathrm{mg} / \mathrm{kg}$ and aspirin as compared to control $(\mathrm{p}<0.05)$ as evidenced by $\%$ inhibition in parentheses.

\begin{tabular}{|c|c|c|c|c|c|c|c|}
\hline \multirow{3}{*}{ Group } & \multirow{3}{*}{$\begin{array}{l}\text { Drug } \\
\text { Dose }\end{array}$} & \multicolumn{4}{|c|}{$\begin{array}{c}\text { Mean Increase in Paw Volume (mean } \pm \text { SEM) in } \mathrm{mL} \\
\text { (\% Inhibition in Parentheses) }\end{array}$} & \multirow{3}{*}{$\begin{array}{c}\text { Weight Change } \\
\text { on 21 st Day } \\
\text { (\% Change in } \\
\text { Parentheses) }\end{array}$} & \multirow{3}{*}{$\begin{array}{l}\text { Arthritis } \\
\text { Index }\end{array}$} \\
\hline & & \multicolumn{2}{|c|}{ Injected Paw (mL) } & \multicolumn{2}{|c|}{ Non-Injected Paw (mL) } & & \\
\hline & & On 0 Day & $\begin{array}{l}\text { On } 5^{\text {th }} \\
\text { Day }\end{array}$ & On 0 Day & On 21st Day & & \\
\hline A (Control) & $\begin{array}{l}2 \mathrm{~mL} \\
\mathrm{PO}\end{array}$ & $0.63 \pm 0.007$ & $\begin{array}{c}1.20 \pm 0.011 \\
(-)\end{array}$ & $0.40 \pm 0.01$ & $\begin{array}{c}1.26 \pm 0.01 \\
(-)\end{array}$ & $-15.6 \pm 0.62$ & $10.02 \pm 0.25$ \\
\hline B (EENA) & $\begin{array}{l}100 \mathrm{mg} / \mathrm{kg} \\
\mathrm{PO}\end{array}$ & $0.67 \pm 0.003$ & $\begin{array}{c}1.12 \pm 0.02 \\
(20.6 \%)\end{array}$ & $0.35 \pm 0.01$ & $\begin{array}{c}1.24 \pm 0.01 \\
(59.2 \%)\end{array}$ & $-10.3 \pm 0.33$ & $8.31 \pm 0.03$ \\
\hline $\mathrm{C}$ (EENA) & $\begin{array}{c}200 \mathrm{mg} / \mathrm{kg} \\
\mathrm{PO}\end{array}$ & $0.73 \pm 0.009$ & $\begin{array}{c}0.79 \pm 0.002 \\
(29.7 \%)\end{array}$ & $0.24 \pm 0.01$ & $\begin{array}{c}0.97 \pm 0.01 \\
(67.4 \%)\end{array}$ & $-6.4 \pm 0.22$ & $5.64 \pm 0.02$ \\
\hline D (EENA) & $\begin{array}{l}400 \mathrm{mg} / \mathrm{kg} \\
\mathrm{PO}\end{array}$ & $0.79 \pm 0.003$ & $\begin{array}{c}0.66 \pm 0.01 \\
(37.9 \%)\end{array}$ & $0.23 \pm 0.006$ & $\begin{array}{c}1.07 \pm 0.02 \\
(73.9 \%)\end{array}$ & $-4.5 \pm 0.11$ & $4.05 \pm 0.15$ \\
\hline E (EENA) & $\begin{array}{l}100 \mathrm{mg} / \mathrm{kg} \\
\mathrm{PO}\end{array}$ & $0.56 \pm 0.006$ & $\begin{array}{l}0.36 \pm 0.006 \\
(42.3 \%)\end{array}$ & $0.19 \pm 0.001$ & $\begin{array}{c}0.48 \pm 0.001 \\
(81.4 \%)\end{array}$ & $-2.6 \pm 0.12$ & $3.32 \pm 0.05$ \\
\hline \multirow{3}{*}{$\begin{array}{c}\text { One-Way } \\
\text { ANOVA }\end{array}$} & $\mathrm{F}$ & 178.6 & 950.5 & 64.34 & 423.3 & 234.1 & 440.2 \\
\hline & $\mathrm{df}$ & 4,25 & 4,25 & 4,25 & 4,25 & 4,25 & 4,25 \\
\hline & $\mathrm{P}$ & $>0.05$ & $<0.05$ & $>0.05$ & $<0.05$ & $<0.05$ & $<0.05$ \\
\hline
\end{tabular}

Table II. Anti-Inflammatory Activity of Ethanolic Extract of Nyctanthes Arbor-Tristis on Chronic Inflammation by AdjuvantInduced Arthritis in Rats

$\mathrm{N}=6$ in each group; $\mathrm{p}<0.05$ vs. control.

\section{DISCUSSION}

Carrageenan induced hind paw oedema in rats is the standard model of acute inflammation. The result of the present study suggests that the ethanolic extract of leaves of Nyctanthes arbor-tristis in doses 100, 200 and $400 \mathrm{mg} / \mathrm{kg}$ significantly suppressed carrageenan induced paw oedema in rats when compared with the control group. The maximum effects of EENA are seen at the dose of 200 and $400 \mathrm{mg} / \mathrm{kg}$ at the end of $3^{\text {rd }}$ and $4^{\text {th }}$ hrs. The test drug at a dose of 400 $\mathrm{mg} / \mathrm{kg}$ was found almost as effective as the standard in inhibiting oedema by carrageenan.

Prostaglandins (PGs) play a significant role in different phases of inflammatory reactions. Moreover, PGs especially PGE1 was reported to act on cell membrane during inflammatory conditions leading to changes in lipoprotein structure of cell membrane. This causes destabilisation of cell membrane furthering to degenerative cellular changes.[17] As 
the process of carrageenan induced paw oedema is considered to involve a biphasic response; the first phase is attributed to the release of histamine, 5-HT and kinins in the first hour, while the second phase is related to the release of prostaglandins like substances in 2 - 3 hours.[18] It appears that the alcoholic extract of dried leaves of Nyctanthes arbortristis inhibit these mediators to account for its antiinflammatory activity.

The model of adjuvant-induced arthritis in rats is a useful tool to study the pathophysiology of rheumatoid arthritis, especially because the experimental model and the human disease share various signs and symptoms.[19] Administration of Freund's complete adjuvant to the rat induces acute inflammation in the injected paw and chronic inflammation and arthritic lesions in the uninjected paw, between 10 and 14 days. The chronic phase is accompanied by splenomegaly and lymphocyte-mediated events.[20]

In our present study, it was seen that there was a gradual increase in the inhibitory activity by Nyctanthes arbor-tristis from $5^{\text {th }}$ day to $21^{\text {st }}$ day. However, aspirin exhibited increase in the inhibitory activity from $6^{\text {th }}$ day onwards. Comparing the efficacy of EENA and aspirin, EENA was found to be equally potent as aspirin.

Chronic inflammation involves the release of inflammatory mediators such as cytokines (IL-IB and TNF- $\alpha$ ), interferon and Platelet-derived growth factors (PGDF). These mediators are mainly responsible for the pain, destruction of bone cartilage which can cause severe disability. The present investigations established the anti-arthritic potential of Nyctanthes arbor-tristis extracts using adjuvant induced arthritis model rats because rats develop a chronic swelling in multiple joints with the influence of inflammatory cells, erosion of joint cartilage and bone destruction. It is very close to human arthritis disease.[21]

Phytochemical studies done on different parts of Nyctanthes arbor-tristis revealed the presence of alkaloids, tannins, triterpenoids, glycosides and flavonoids as well as the significant antioxidant properties of phenolic compounds of this plant.[22,23] In previous phytochemical studies, phytoconstituents like steroids, flavonoids, alkaloids, terpenoids and tannins have been shown to possess antiinflammatory and analgesic activity.[24,25] Flavonoids are known to inhibit the enzyme prostaglandin synthetase, more specifically the endoperoxidase.[26] Some flavonoids are predominant inhibitors of either cyclooxygenase or lipoxygenase. ${ }^{[27,28]}$ Isolated arbortristoside-A from ethanolic extracts of seeds of $\mathrm{N}$. arbor-tristis is proved to possess significant and dose dependent anti-inflammatory activity.[29] Since prostaglandins are involved in the pain perception and are inhibited by flavonoids, it could be suggested that the anti-inflammatory effect of Nyctanthes arbor-tristis might be due to its inhibitory action on PG biosynthesis.

It was seen that EENA have significant anti-inflammatory and anti-arthritic activity. So it can be used as a potential natural source of inflammation disorders by preventing or slowing the progress of symptoms of arthritis. The study should be further extended to identify and characterise the most active bioactive fractions and phytoconstituents, which are responsible for the observed significant antiinflammatory and anti-arthritic activity and to understand the mechanism of action against adjuvant-induced arthritis in rats.

\section{CONCLUSION}

From the above results, it was found that the leaves of Nyctanthes arbor-tristis have significant anti-inflammatory and anti-arthritic activity against both acute and chronic models of inflammation. This establishes its traditional uses in acute inflammatory conditions. So, these can be used as a potential natural source of inflammatory disorders by preventing or slowing the process of symptoms of inflammation. The study can be further extended to identify and establish the most bioactive fractions and the phytoconstituents and to understand the mechanism of action against the inflammation and its clinical uses.

\section{ACKNOWLEDGEMENT}

We are thankful to Dr. LR Saikia, Professor, Department of Life Sciences, Dibrugarh University, Assam, for helping us with the taxonomical identification of the plant.

\section{REFERENCES}

[1] Turner RA. Anti-inflammatory agents, screening methods in pharmacology. New York: Academic Press 1965;1:153-62.

[2] Ahlmen M, Svensson B, Albertsson K, et al. Influence of gender on assessments of disease activity and function in early rheumatoid arthritis in relation to radiographic joint damage. J Ann Rheum Dis 2010;69(1):230-3.

[3] Campbell SM. Rheumatoid arthritis: current strategies. Hospital Medicine 1988;34:29.

[4] Scott DL, Shipley M, Dawson A, et al. The clinical management of rheumatoid arthritis and osteoarthritis: strategies for improving clinical effectiveness. British Journal of Rheumatology 1998;37(5):546-54.

[5] Pincus T, Marcum SB, Callahan LF. Longterm drug therapy for rheumatoid arthritis in seven rheumatology private practices. II. Second line drugs and prednisone. The Journal of Rheumatology 1992;19(12):1885-94.

[6] Shandhar HK, Kaur M, Kumar B, et al. An update on Nyctanthes arbortristis Linn. Journal of International Pharmaceutica Sciencia 2011;1(1):77-86.

[7] Kirtikar KR, Basu BD, Singh B, et al. Indian medicinal plants. 1975;1(2):2392-3.

[8] Nairn JG. Solutions, emulsions, suspension and extracts. In: Gennaro A, Marderosian AD, Hanson GR, et al. The science and practice of pharmacy. 20th edn. Philadelphia, Lippincott Williams and Wilkins 2000: p. 721-52.

[9] OECD Guidelines for testing of Chemicals (Internet) France: Health effects: Test No. 425: acute oral toxicity: up and down procedure. Section 4, Organization for Economic Cooperation and Development OECD Publishing 2006: p. 1-27.

[10] Das S, Sasmal D, Basu SP. Evaluation of CNS depressant activity of different plant parts of Nyctanthes arbortristis Linn. Indian J of Pharma Sci 2008;70(6):803-6.

[11] Chattopadhyay RN, Chattopadhyay RR, Roy S, et al. A simple method for plethysmometric measurement of paw volume of small laboratory animals in the evaluation of anti-inflammatory effect. Bull Calcutta Sch Trop Med 1988;36:5-8. 
[12] Olajide OA, Awe SO, Makinde JM, et al. Studies on the anti-inflammatory, anti-pyretic and analgesic properties of Alstonia boonei stem bark. J Ethnopharmacol 2000;71(1-2):179-86.

[13] Diniz RS, Agshikar NV, Abraham GJS. Antiinflammatory effects of hydrochlorthiazide. Indian $\mathrm{J}$ of Pharmacol 1978;10:15-9.

[14] Vogal HG. Antiarthrotic and immunomodulatory activity. Drug discovery and evaluation. Complete discovery and enlarged. 2nd edn. Germany: Springer Publishing 2002: p. 802-05.

[15] Gu WZ, Brandwein SR. Inhibition of type II collagen induced arthritis in rats by triptolide. Int J Immunopharmacol 1998;20(8):389-400.

[16] Rao KV. Multiple comparision test procedures. In: Rao KV, Balakrishnan N. eds. Biostatistics. $1^{\text {st }}$ edn. New Delhi, India: Jaypee Brothers Medical Publishers 1999: p. 273-8.

[17] Rao BA, Sisodia P, Sattur PB. Erythrocyte membrane stabilization by Enfenamic acid. Indian J Expt Biol 1987;25:489-90.

[18] Vinegar R, Schreiber W, Hugo R. Biphasic development of carrageenan edema in rats. J Pharmacol Exp Ther 1969;166(1):96-103.

[19] Pearson CM, Wood FD. Studies of arthritis and other lesions induced in rats by the injection of mycobacterial adjuvant. VII. Pathologic details of the arthritis and spondylitis. Am J Pathol 1963;42(1):7395.

[20] Van Arman CG. Pathway to adjuvant arthritis. J Fed Proc 1976;35(13):2442-6.
[21] Eric CV, Lawrence JL. Rheumatoid arthritis and its therapy. In: The Textbook of therapeutics drugs and disease management. Baltimore: Williams and Wilkins Company 1996.

[22] Srinivasan KK, Goomber A, Kumar SS, et al. Phytochemical, antioxidant and antimicrobial study of flowers of Nyctanthes arbor-tristis Linn. Pharmacologyonline 2011;2:16-21.

[23] Nagavani V, Raghava RKV, Ravi KC, et al. In vitro screening of Nyctanthes arbor-tristis flowers for antioxidant activity and identification of polyphenols by RP-HPLC. Pharmacologyonline 2010;2:57-78.

[24] Das S, Halder PK, Pramanik G, et al. Evaluation of antiinflammatory activity of Cleodendron infortunatum Linn. Extract in rats. Global J Pharmacol 2010;4:48-50.

[25] Chakraborthy GS. Evaluation of immunomodulatory activity of Cassia auriculata Linn. Journal of Herbal Medicine and Toxicology 2009;3:111-3.

[26] Ramaswamy S, Pillai NP, Gopalkrishnan V, et al. Analgesic effect 0-( $\beta$-hydroxy ethyl) rutoside in mice. Indian J Exp Biol 1985;23(4):219-20.

[27] Rajnarayana K, Reddy MS, Chaluvadi MR, et al. Bioflavonoids classification, pharmacological, biochemical effects and therapeutic potential. Indian J Pharmacol 2001;33:2-16.

[28] Trease GE, Evans WC. Phenolic compounds and tannins, Pharmacognosy. London: Baillier Trindall $4^{\text {th }}$ edn. 1972: p. 146-8.

[29] Das S, Sasmal D, Basu SP. Anti-inflammatory and antinociceptive activity of arbortristoside-A. J Ethnopharmacol 2008;116(1):198-203. 